\title{
LIBERTARIAŃSKIE KONCEPCJE PAŃSTWA W UJĘCIU BUCHANANA, NOZICKA I FRIEDMANA
}

\author{
LIBERTARIAN CONCEPTS OF THE STATE \\ FROM THE PERSPECTIVE \\ OF BUCHANAN, NOZICK, AND FRIEDMAN
}

Hubert Staśkiewicz*

\begin{abstract}
- ABSTRAKT
Artykuł poświęcony jest minarchistycznym i anarchokapitalistycznym ideom państwa. Prezentuję w nim stanowiska takich libertariańskich myślicieli, jak James M. Buchanan, Robert Nozick oraz David Friedman. Tylko ten ostatni jest poplecznikiem zorganizowania społeczeństwa bez potrzeby istnienia władz politycznych i odrzuca nawet tak podstawowe zadania państwa, jak zapewnienie funkcjonowania policji, wojska i wymiaru sprawiedliwości.
\end{abstract}

Słowa kluczowe: minarchizm, anarchokapitalizm, James M. Buchanan, Robert Nozick, David Friedman

* Uniwersytet Zielonogórski, Instytut Filozofii.

Keywords: minarchism, anarcho-capitalism, James M. Buchanan, Robert Nozick, David

Friedman
This article is devoted to the minarchism and anarcho-capitalism ideas of the state. I present the views of libertarian thinkers such as James M. Buchanan, Robert Nozick, and David Friedman. Only only the last one mentioned the latter is a supporter of the organization of society without the need for political authorities and rejects even such basic tasks of the state, to ensure the functioning of the police, army, and judiciary. 


\section{WSTĘP}

Idee wolnościowe wywierały ogromny wpływ podczas trwania XIX-wiecznego stulecia. Diametralne zmiany przyniósł wiek XX. Ustanowienie w roku 1913 w USA potężnego banku centralnego - Systemu Rezerwy Federalnej (FED) w połączeniu z odrzuceniem oparcia waluty na złocie i przejściem na pieniądz fiducjarny (papierowy) spowodowało, że „wzrost światowego zadłużenia osiągnął stan, o jakim nie słyszano na przestrzeni całej historii ludzkiej cywilizacji” (Paul, 2008, s. 157). Rozpoczęcie w roku 1914 pierwszej wojny światowej, czyli pierwszego w dziejach konfliktu totalnego, w którym na masową skalę cierpieli również cywile, przyczyniło się do rozszerzenia zakresu władzy wykonawczej (prezydenta i rządu), uchwalenia nowych ustaw, rozrostu biurokracji, potrzebnej do sprawowania większej kontroli nad społeczeństwem oraz doprowadziło w późniejszych latach do wybuchu rewolucji socjalistycznej. Faktem jest również, iż w okresie ostatnich stu lat ustawodawcy praktycznie wszystkich państw na świecie stopniowo powiększali swoje kompetencje w różnych dziedzinach życia społecznego i pobierali (w formie wysokich podatków) coraz więcej pieniędzy od swoich obywateli.

Przez cały XX wiek wszystkim wyżej wymienionym zjawiskom sprzeciwiali się zwolennicy libertarianizmu, którzy odwoływali się do idei wolności oraz autonomii jednostek (pozycja jednostek powinna być niezwykle silna, społeczeństwo należy postrzegać jedynie jako sumę jednostek). Specyfika myśli libertariańskiej tkwi w jej jedności w różnorodności. Podstawowym sporem w zakresie filozofii polityki jest to, czy w ogóle konieczne jest istnienie państwa, czy możliwa jest alternatywna forma organizacji społecznej. W niniejszej pracy przybliżam ten problem, prezentując założenia państwa minimalnego, ultraminimalnego oraz propozycje zniesienia instytucji państwowej, czyli prywatyzację jego usług i zastąpienie porządku etatystycznego porządkiem wolnego rynku.

\section{KONSTYTUCJONALIZM JAMESA BUCHANANA}

James M. Buchanan (nie mylić z prezydentem USA Jamesa Buchananem, urzędującym w latach 1857-1861) zaliczał się do bardzo wąskiego grona kontraktualistycznych libertarian, tzn. rozważających i aprobujących powstanie państwa $\mathrm{w}$ wyniku umowy społecznej i dlatego jego koncepcja zasługuje na uwagę. 
Myśliciel wyszedł od stanu natury o treści zbliżonej do wersji badanej przez Thomasa Hobbesa. „W stanie tym nie ma ani rządu, ani żadnych innych graczy politycznych, są jedynie osoby ze swoimi partykularnymi żądaniami, dążące do realizacji jednostkowych celów" (Modrzejewska, 2010, s. 180). Stan ten nazywa się naturalną dystrybucją. Jednostki dzielą czas pomiędzy działalność produkcyjną, ochronną i grabieżczą. Nie istnieją żadne koalicje i wszyscy są w stanie wojny ze wszystkimi. Buchanan (1975) podzielał też tezę, iż w tym świecie każdy ma prawo do wszystkiego. Nie egzystują więc żadne naturalne prawa, a jedynie prawo silniejszego.

„Z czasem, racjonalne jednostki, kierowane egoistycznym interesem, zauważają niedogodności tej sytuacji i spostrzegają, że zawarcie porozumienia, zmniejszającego akty agresji i grabieży, będzie dla nich ogromną korzyścią" (Modrzejewska, 2010, s. 181). Pragmatyczna chęć maksymalizacji użyteczności doprowadza więc ludzi do porzucenia stanu natury. Umowa społeczna zostaje podzielona na dwa stadia: umowę konstytucyjną i umowę pokonstytucyjną. Zaczątkiem umowy konstytucyjnej jest wynegocjowana umowa rozbrojeniowa, stanowiąca pierwszy krok na drodze porzucenia anarchistycznej dżungli (Buchanan, 1975). „Moment, w którym wszystkie osoby zgadzają się na rozbrojenie, to także chwila na ustanowienie własności prywatnej; jednostki ustalają więc swój podział w dobrach" (Modrzejewska, 2010, s. 182).

Inspirującym fragmentem teorii Buchanana było wdrożenie na tym etapie przejętej od Knuta Wicksella (1896), idei jednomyślności, opracowanej pod koniec XIX wieku. Autor uważał, że jednomyślność jest możliwa do osiągnięcia i prawdopodobna, gdyż stoi za nią ważki cel zmniejszenia wydatków na ochronę, a to skłania do powołania państwa protektywnego, które nie będzie władne do podejmowania decyzji o charakterze politycznym (zgodnie z myślą: „najpierw stworzyć i umocnić rząd, a potem nałożyć na niego ograniczenia”), co pozwoli również jednostkom na ich rozwój ekonomiczny.

Państwo powstaje więc tylko po to, by zdefiniować i chronić własność prywatną oraz jej obrót. „Do jego zadań należy ustalanie norm prawnych oraz roszczeń poszczególnych osób, a także ustalanie sankcji oraz procedur ich nakładania na jednostki łamiące normy prawa. Jak jednak podkreślał Buchanan, funkcje te wynikają jedynie z zawartej przez ludzi umowy konstytucyjnej, a nie są przynależne państwu jako takiemu” (Modrzejewska, 2010, s. 183).

Pełna umowa konstytucyjna składa się więc z następujących elementów:

„1) reguł nakładających ograniczenia na zachowania jednostek, 
2) reguł określających stan posiadania poszczególnych osób oraz przysługujące im prawa do własności,

3) reguł określających warunki i sposoby egzekwowania zasad ustalonych w punkcie 1. i 2., 4) oraz reguł, którymi będzie się kierować zbiorowość, podejmując decyzje dotyczące wytwarzania dóbr publicznych" (Buchanan, 1975, s. 68-71).

Drugim stadium jest okres pokonstytucyjny. O ile pierwszy etap stworzył ramy i wyznaczył zasady gry, o tyle drugi obejmuje już stosowanie tych reguł. Rezygnuje się tu z wymogu jednomyślności, co utwierdza w przekonaniu, iż pierwsza faza należała do istotniejszych. „Ulega także modyfikacji funkcja państwa: korzysta ono również z dóbr publicznych, które zostały wyprodukowane przez zbiorowość, co powoduje, że poza ochroną, zajmuje się ono wytwarzaniem, staje się państwem produktywnym, a nie tylko protektywnym" (Modrzejewska, 2010, s. 184).

Innowacyjnym elementem jest zamysł o zmianie konstytucyjnego status quo, renegocjacji i ponowieniu umowy (Buchanan, 1975). W propozycji tej widać wpływ myśli Lysandera Spoonera - adwersarza konstytucji, jako aktu wiążącego potomnych (Modrzejewska, 2010). Może to być jednak trudne do dokonania, ponieważ uprzywilejowani, w istniejącym stanie rzeczy, nie wyrażą na to zgody (Barry, 1984). Należy jednak próbować za wszelką cenę, gdyż działania rządu, przekraczające zadania obronne, niosą poważne zagrożenia (Naverson, 1988). Zdaniem Buchanana (1975) zagrożenia te już doprowadziły do stanu konstytucyjnej anarchii, w której prawa jednostek zależą od decyzji polityków, i właśnie dlatego żąda przeprowadzenia konstytucyjnej rewolucji, czyli de facto powrotu do umowy konstytucyjnej.

Efektem tej refleksji była teoria wyboru publicznego (szczególnej wersji teorii racjonalnego wyboru), która badała przede wszystkim proces kształtowania instytucji w sferze polityki. Posługiwała się ona tymi samymi prawami i metodami, jakich ekonomiści używają do analizy ludzkich zachowań na rynku. Fundamentami tej teorii są takie elementy, jak (Wilkin, 2005):

1) indywidualizm metodologiczny,

2) zasada maksymalizacji lub optymalizacji,

3) idea optimum społecznego,

4) koncepcja równowagi systemu,

5) idea kapitału społecznego,

6) koncepcja instytucji,

7) założenie o społecznych źródłach uprawnień,

8) możliwość poprawy użyteczności przez zrzeczenie się kontroli. 
Teoria ta dostarcza cennej wiedzy o mechanizmach i prawidłowościach funkcjonowania społeczno-politycznych instytucji (Buchanan, 1975). Okazuje się, że ludzie w nich pracujący motywowani są w głównej mierze przez swoje własne interesy i ambicje, a nie przez poczucie obowiązku wobec społeczeństwa. Chociaż czasami działają w pewien sposób, w trosce o dobro publiczne, źródłem i dominującym bodźcem zachowań jest jednak egoizm, co świadczy skądinąd o racjonalności tych jednostek. Buchanan sformułował zatem hipotezę Lewiatana, zgodnie z którą instytucje państwowe, wskutek takiego zachowania polityków i biurokratów oraz wad procesów wyborczych, rozszerzają się stale, a ograniczając wolności obywatelskie - stają się Lewiatanem.

Rezultatem ciągłego rozrostu sektora publicznego jest nadmierna ekspansja budżetu, tak zwany reżim stałych deficytów budżetowych, którą potęgują procedury demokratyczne, zakładające podejmowanie decyzji na podstawie większości głosów, a zatem nieliczenie się z interesami mniejszości. Koszty realizacji decyzji podjętych przez większość muszą ponosić wszyscy, zatem i mniejszość. Taka dyktatura większości powoduje ignorowanie przez nią obciążeń narzuconych mniejszości oraz zmniejszenie kosztu, który musiałaby ponieść owa większość, gdyby nie przymusiła wszystkich do finansowania danego projektu.

Pomysłem na uporządkowanie i umoralnienie przestrzeni publicznej jest wdrożenie konkluzji nurtu zwanego nową ekonomią instytucjonalną, a ściślej ekonomią konstytucyjną, zajmującą się analizą blokowania aktywności jednostek i podmiotów gospodarczych przez przyjęty ład społeczno-gospodarczy. Za dzieło, które dało początek tej idei, uważa się Rachunek zgody Buchanana i Tullocka (1979). Sami autorzy opisywali ją jako „próbę wyjaśnienia właściwości funkcjonowania prawno-instytucjonalno-konstytucyjnych reguł, stanowiących ograniczenia dla działań aktorów ekonomicznych i politycznych oraz określających ramy, w których zwykłe wybory aktorów ekonomicznych i politycznych się dokonują".

Samą konstytucję Buchanan (1977) definiował porównywalnie jako zestaw zasad, które ograniczają aktywność osób w dążeniu do osiągnięcia własnych kresów i celów. Oczywiście, konstytucja definiowana w ten sposób obejmowała cały system prawa, a nie tylko najwyższy rangą akt normatywny. Zwracano przy tym uwagę, iż zarówno istnienie, jak i brak konstytuujących norm może generować straty. To trafia właśnie w sedno sprawy, bo obecne prawo wiąże i utrudnia życie prywatnym jednostkom, a nie władzy państwowej, a powinno być dokładnie odwrotnie - efektywny i sprawiedliwy system musi pozostawiać swobodę ludziom, którzy wyraźnie ograniczą i legitymizują reprezentantów elit 
i instrumenty polityczne. Wnioskiem dla polityki gospodarczej jest więc określenie optymalnego, czyli praktycznie zerowego bądź bardzo minimalnego poziomu i zakresu ingerencji państwa w gospodarkę, który winien zostać ustanowiony w nowym ładzie konstytucyjnym (analogia do Konstytucji wolności Friedricha von Hayeka).

Reasumując teorię Buchanana, najlepiej przytoczyć jego słowa: „często mówię o sobie, że jestem filozoficznym anarchistą. W moim wyimaginowanym społeczeństwie idealnym wzajemnie szanujące swoje prawa jednostki żyją i współdziałają ze sobą tak, jak sobie tego życzą, bez konieczności nadzoru ze strony jakiejś struktury politycznej. Mój praktyczny ideał jest jednak nieco bardziej przyziemny i opiera się na przeświadczeniu, że jednostki nie będą w stanie osiągnąć takiego standardu zachowań, by wymarzona przeze mnie anarchia mogła funkcjonować właściwie. Dlatego sądzę, iż w uznaniu dla tej ułomności natury ludzkiej, jednostki zgodzą się na ustanowienie praw i mechanizmów ich egzekucji, umożliwiających osiągnięcie możliwie najbardziej wolnego społeczeństwa. Na tej praktycznej płaszczyźnie jestem konstytucjonalistą i zwolennikiem społeczeństwa kontraktowego" (Buchanan, 1975, s. 223).

\section{MINARCHIZM ROBERTA NOZICKA}

Idee Roberta Nozicka były reakcją na teorię państwa w ujęciu Johna Rawlsa. Filozofowie dyskutowali przede wszystkim na temat zasady sprawiedliwości. Według Rawlsa uzasadniała ona redystrybucyjną funkcję państwa, a w krytyce Nozicka - dawała państwu zbyt wiele uprawnień, prowadzących do naruszenia własności prywatnej i wolności gospodarczej. „Polemizując z Rawlsem, Nozick zakwestionował główne tezy teorii sprawiedliwości dystrybutywnej. Nie ograniczył się jedynie do krytyki, w pierwszej części swej książki przedstawił bowiem własną, zgodną z duchem klasycznego liberalizmu koncepcję sprawiedliwego posiadania ${ }^{1}$, która pełni w jego systemie funkcję teorii sprawiedliwości” (Miklaszewska, 2001, s. 113).

Sprawiedliwość libertariańska w modelu Nozicka realizowała się w państwie nieingerującym w gospodarkę. Filozof określał bowiem sprawiedliwość nie ze względu na rezultaty (mierzone np. za pomocą ilości dóbr dostępnych dla jednostek lub ich użyteczności), ale ze względu na procedury. Była więc ona

\footnotetext{
1 Zwaną również teorią uprawnień bądź teorią legalistyczną.
} 
sprawiedliwością proceduralną, formalną. Teoria uznawała za sprawiedliwą taką redystrybucję, która gwarantowała respektowanie fundamentalnych praw jednostek, takich jak: prawo do życia, wolność wyboru czy prawo do produktu własnej pracy.

Głównymi założeniami tej koncepcji były trzy zasady (Nozick, 2010):

1) sprawiedliwego nabywania (nawiązywała do Locke’owskiej idei zawłaszczania rzeczy niczyich poprzez pracę, nadającą im wartość $)^{2}$,

2) sprawiedliwego i produktywnego transferu (tyczyła się dobrowolnej wymiany rzeczy posiadanych),

3) naprawy krzywdy i niesprawiedliwości (mówiła o sytuacji, gdy ktoś zawłaszczał rzeczy niezgodnie z prawem) $)^{3}$.

Z kolei w przypadku Rawlsa mieliśmy do czynienia ze sprawiedliwością dającą się zaadaptować w państwie socjalliberalnym ${ }^{4}$. O ile pierwsza reguła sprawiedliwości Rawlsa ${ }^{5}$, co do zasady, nie była przedmiotem krytyki Nozicka, o tyle druga już zdecydowanie tak. Brzmiała ona następująco: „Nierówności społeczne i ekonomiczne mają być tak ułożone, aby (Rawls, 1994, s. 87):

1) były z jak największą korzyścią dla najbardziej upośledzonych (zasada sprawiedliwego oszczędzania/dyferencji),

2) były związane z dostępnością do urzędów i stanowisk dla wszystkich, w warunkach autentycznej równości szans".

Rozwijając tę myśl:

2 Dla Murraya Rothbarda oraz Israela Kirznera ziemia i wszelkie zasoby naturalne były pozbawione w stanie natury posiadacza. Można więc dokonywać ich zawłaszczenia bez jakichkolwiek ograniczeń. Samo odkrycie cennych zasobów tworzy bowiem ekonomiczną wartość.

${ }^{3}$ Jeśli znamy prawowitego właściciela lub spadkobiercę pozbawionych zasobów, powinniśmy mu je oddać. Przykładowo, w latach siedemdziesiątych i osiemdziesiątych XX wieku sądy federalne w USA wydawały orzeczenia nakazujące zwrot ziem bądź zadośćuczynienia w postaci wypłaty ekwiwalentów pieniężnych dla potomków rdzennych mieszkańców Ameryki (Indian).

${ }^{4}$ Uważam, że powszechnie panująca opinia, jakoby Rawls był liberałem, jest zdecydowanie niezgodna z jego poglądami, gdyż należał on tylko do zwolenników liberalizmu politycznego, ale nie gospodarczego. W kwestiach ekonomicznych był on bliższy idei umiarkowanego państwa opiekuńczego.

${ }^{5}$ Każda osoba powinna mieć równe prawo do jak najszerszego całościowego systemu równych podstawowych wolności, dającego się pogodzić z podobnym systemem dla wszystkich. Podstawowe wolności obywatelskie to, pisząc oględnie, bierne i czynne prawo wyborcze, wolność słowa, myśli, prawo do zgromadzeń, prawo do własności prywatnej, nietykalność osobista itp. Zasada wolności miała charakter absolutny i nie mogła być złamana. Pierwsza zasada miała zwykle prawo pierwszeństwa nad drugą zasadą. Jednakże wolności na różnych płaszczyznach bywały ze sobą w konflikcie, dlatego czasem było konieczne rezygnowanie z ich części w celu uzyskania jak najobszerniejszego systemu praw jednostki. 
Ad 1. Zgodnie z zasadą dyferencji wszelkie odejścia od zasady wolności miały uzasadnienie jedynie $\mathrm{w}$ przypadku, gdy wiązały się z korzyścią dla jednostek znajdujących się w najgorszym położeniu. Stwierdzenie to mówiło o przynajmniej częściowym egalitaryzmie Rawlsa. Jego argumentacja za tą tezą brzmiała, że czynniki od nas niezależne (np. rodzina, w której się rodzimy) nie powinny determinować naszych szans życiowych czy perspektyw. Rawls zwracał także uwagę, że nasze wrodzone talenty nie są w żadnym stopniu naszą zasługą, w związku z czym zyski, jakie prawdopodobnie będziemy czerpać z ich tytułu, są również niezasłużone. Taka redystrybucja dochodów od osób bardziej uzdolnionych (ergo statystycznie bogatszych) do osób mniej zdolnych ma służyć zatem sprawiedliwości ${ }^{6}$.

Ad 2. Drugi punkt mówił o merytokracji. Autentyczna równość szans nie oznaczała tylko, że stanowiska nadawane będą jedynie na podstawie przygotowania merytorycznego osoby, ale że każda z osób będzie miała równe szanse nabyć kwalifikacje potrzebne do objęcia konkretnego stanowiska. Często uważano, że zasada autentycznej równości szans wymaga większej dozy równości niż zasada dyferencji, gdyż nawet jeśli nierówności będą z jak największą korzyścią dla najbardziej upośledzonych, może to oznaczać, że nie doprowadzą one do sytuacji zawartej w punkcie drugim.

Idee Rawlsa prezentowały więc idealistyczny, oparty na umowie społecznej postulat sprawiedliwości, według którego państwo będzie rozdzielać dobra zgodnie z zasadami wyrównywania podziałów w społeczeństwie (Teluk, 2006). Nozick negował równościowe przesłanie Rawlsa, wykazując, że redystrybucja dyskryminuje jednostki pracowite i przedsiębiorcze w imię egalitaryzmu (Miklaszewska,

${ }^{6}$ Nozick wręcz ośmieszył ten postulat, powołując się na słynny już przykład koszykarza Wilta Chamberlaina. W ramach eksperymentu myślowego autor najpierw nakazał czytelnikom wyobrazić sobie pewien stan społeczny D1, zgodny z jakąś dystrybucyjną zasadą teleologiczną (mogła być nią dystrybucja egalitarystyczna, zbliżona do teorii zaproponowanej przez Rawlsa). Następnie przytoczył opowieść. Przypuśćmy, że niezwykle zdolny i nieprzeciętnie utalentowany Chamberlain podpisuje kontrakt ze swoją drużyną, który oprócz pensji gwarantuje mu 25 centów od każdego biletu sprzedawanego na mecze rozgrywane na własnym boisku. Widzowie, przyciągnięci jak magnes widowiskową grą koszykarza, za każdym razem wrzucają osobne 25 centów do puszki z nazwiskiem Chamberlain. W ten sposób po zakończeniu owocnego sezonu na koncie sportowca uzbierała się dodatkowa kwota w wysokości 250000 dolarów. Powstał więc nowy stan D2, który jest już niezgodny z przyjętym schematem. Czy jednak ktokolwiek może protestować, uznając tę kumulację kapitału za niesprawiedliwą? Przecież wszyscy ludzie: kibice, menadżerowie drużyny, nie wspominając już o samym Chamberlainie, w sposób dobrowolny dysponowali swoją własnością i zgodzili się na przejście z D1 do D2. Opodatkowanie teraz tej zapłaty za pracę stałoby na równi z pracą przymusową, ponieważ konfiskowanie części pieniędzy to zabieranie komuś nadgodzin pracy. 
2001). „Wyższe opodatkowanie bogatych na rzecz redystrybucji względem biednych godzi nie tylko w prawa własności, lecz powoduje absurdalną zależność ludzi bogatych od redystrybucyjnych wymagań, roszczeń i potrzeb beneficjentów systemu socjalnego. Opodatkowanie polega na wywłaszczaniu jednostki przez państwo, czego nie można zaakceptować z punktu widzenia jednostki" (Teluk, 2006, s. 109). Dlatego Nozick „ostro atakował zasadę równości szans, mającą obowiązywać w państwie urzeczywistniającym teorię sprawiedliwości rozdzielczej. Zastosowanie tej zasady w praktyce prowadzi do niesprawiedliwości: polepsza się bowiem sytuacje ludzi znajdujących się w gorszych warunkach bytowych poprzez zabranie dóbr będących własnością osób, którym się lepiej powodzi" (Miklaszewska, 2001, s. 120).

Dlatego Nozick, rozpoczynając swoje dzieło, napisał: „zasadniczym przedmiotem tej pracy jest natura państwa, jego uprawnione funkcje i jego usprawiedliwienie, jeśli jakieś ma. Co, jeśli cokolwiek, wolno państwu i jego funkcjonariuszom? Jak wiele miejsca prawa jednostki pozostawiają dla państwa? Dlaczego nie anarchia?"7 (Nozick. 2010, s. 19). Autor, mimo wszystko, anarchistą nie był, choć $\mathrm{z}$ anarchistami sympatyzował. Anarchia stanowiła dla niego wyłącznie punkt odniesienia do rozważań nad teorią państwa. Co więcej, zmierzał do wykazania, że będzie ono lepsze od możliwie najlepszej hipotetycznie przyjętej sytuacji anarchicznej, w której „ludzie generalnie przestrzegają ograniczeń moralnych i działają tak, jak powinni. Starania zaś, jakie podejmują w celu ustanowienia i utrzymania państwa, winny być same w sobie dopuszczalne moralnie" (Nozick, 2010, s. 20).

Nozick, projektując swą wizję, twierdził, że prędzej czy później wykluwa się ono z chaosu stanu natury. Powtarzał on za Johnem Lockiem, że „w stanie natury człowiekowi wolno samemu egzekwować swe prawa, bronić się, ściągać zadośćuczynienie i karać (lub przynajmniej ze wszelkich sił próbować to robić), innym wolno dołączyć na jego wezwanie i stanąć w jego obronie" (Nozick, 2010, s. 27). Mogą „pomóc mu w uzyskaniu od przestępcy tego, co mogłoby wynagrodzić krzywdę, jaką on wyrządził" (Locke, 1992, s. 168-169). Jednostkom wolno więc stowarzyszać się w celu wzajemnej ochrony (u Locka, jest to aspekt naturalnej wspólnotowości ludzkiej).

${ }^{7}$ Nozick traktował to pytanie jako jedno z fundamentalnych z zakresu filozofii politycznej, bowiem jeśli doktryna anarchistyczna mogłaby się obronić, przedmiot filozofii polityki pozbawiony zostałby sensu. 
Skoro ludzie mają prawo do łączenia swoich sił w egzekwowaniu przestrzegania prawa natury, jednostki korzystają z tego i zrzeszają się przeciwko naruszycielom istniejącego porządku. „Stowarzyszenia te, gdyby stanęly wobec konfliktu pomiędzy poszczególnymi członkami należącymi do nich, mogłyby stosować politykę nieinterwencji. Wówczas jednak mogłoby dojść do rozłamu wewnątrz stowarzyszenia bądź też potencjalni agresorzy przystępowaliby do jak największej liczby zrzeszeń, chcąc zapewnić sobie bezkarność. Dlatego też te ze stowarzyszeń ochrony, które przetrwałyby, odeszłyby od polityki nieinterwencji" (Modrzejewska, 2010, s. 159). Opracowałyby one „pewną procedurę określania, jak należy działać, kiedy pewni członkowie oskarżają innych o naruszenie praw" (Nozick, 2010, s. 28).

W rezultacie zdarzeń, wyjaśnianych ruchem „niewidzialnej ręki” (koncepcja Adama Smitha), spontanicznie, w wyniku walki bądź ugody, powstaje dominująca agencja ochrony, którą jednak nie można jeszcze nazwać państwem. Nozick używał bowiem Weberowskiej definicji państwa ${ }^{8}$ : ,posiada ono monopol na stanowienie siły na danym obszarze geograficznym" (Weber, 1984, s. 156). Przeważające stowarzyszenie zapewniające bezpieczeństwo nie ma więc prawa wyłączności do użycia siły na swoim terytorium. Nie może ukarać każdego winnego, zapewnić ochronę wszystkim osobom, także tym niezrzeszonym $\mathrm{w}$ dominującej agencji.

Jednak Nozick sądził, że będzie to kolejny etap w jej rozroście i stanie się ona państwem ultraminimalnym. Posiada ono monopol użycia siły na całym obszarze „Z wyjątkiem sytuacji bezpośredniej samoobrony koniecznej, a więc wyklucza prywatny lub realizowany przez agencję odwet za wyrządzoną krzywdę i prywatne egzekwowanie zadośćuczynienia" (Nozick, 2010, s. 43). Jednocześnie, „państwo ultraminimalne pozostaje w całkowitej zgodzie z interesami ludzi, którzy są chronieni - tylko osoby dobrowolnie płacące za ochronę uzyskują protekcję od państwa. Choć zabrania ono używania przemocy osobom prywatnym przeciwko komukolwiek, to broni jedynie te jednostki, które wnoszą opłatę na rzecz funkcjonowania systemu" (Modrzejewska, 2010, s. 160-161).

Filozof uzasadniał zakaz prywatnego odwetu i egzekwowania zadośćuczynienia w sposób następujący: każda osoba ma prawo, by jej wina została dowiedziona za pomocą najmniej niebezpiecznej ze znanych procedur wykazywania winy,

${ }^{8}$ Krytykowanej przez większość libertarian. Nozick przywoływał jednak rozważania, że państwo może istnieć bez rzeczywistego monopolizowania siły, podczas gdy nie upoważniło nikogo innego do jej użycia. 
to znaczy za pomocą procedury, którą cechuje najniższe prawdopodobieństwo uznania za winną osoby niewinnej. Jak celnie zauważono w literaturze podmiotu, tylko państwo ultraminimalne będzie sprawować rolę „ostatecznego interpretatora i egzekutora powierzonych mu naturalnych praw" (Porębski, 1999, s. 173).

Końcowy etap to przejście z kraju ultraminimalistycznego do państwa minimalnego o charakterze „nocnego stróża” (idea Smithowska). Państwo takie musiałoby zastosować przymus w postaci środków redystrybucyjnych. Podczas gdy różne osoby płaciłyby za ochronę więcej, mniej lub nic, państwo broniłoby i ochraniałoby wszystkich ludzi, znajdujących się w jego jurysdykcji.

Osiągnięcie tego poziomu „demokratyzacji”, w opinii Nozicka, to konieczność moralna. To jedyny sens, usprawiedliwienie, ale i zarazem warunek sine qua non egzystencji instytucji państwowej. „Państwo minimalne powstało, aby chronić prawa jednostki w sytuacji anarchii. Państwo minimalne chroni anarchię" (Lemieux, 1983, s. 158). W tym libertariańskim społeczeństwie znajduje się miejsce dla całej mozaiki grup czy organizacji, dlatego obok siebie pokojowo współistnieć mogą różnorodne społeczności od komunistów do narodowych katolików (Legutko, 1997). Filozof poddawał jednak krytyce wszelkie bardziej rozwinięte struktury państwowe, wybiegające poza funkcje ochrony życia, wolności i własności. Rozbudowana forma państwa sprzyja nadużyciom oraz niesprawiedliwościom, dlatego jest moralnie naganna.

Jak łatwo się domyślić, przyzwolenie Nozicka na minimalną redystrybucję i monopol państwa w kwestii bezpieczeństwa wywołało burzliwą reakcję anarchokapitalistów, twierdzących, że koncepcja ta łamie prawa jednostek i ignoruje wszechobecną tendencję państw do rozszerzania swoich kompetencji. „Nie mamy do czynienia z niewidzialną ręką, lecz istną żelazną pięścią” (Childs, 1977, s. 24). Co więcej, „państwo powstałe zgodnie z wersją zaproponowaną przez Nozicka jest w istocie prywatną własnością firmy, nie posiada żadnego ustroju konstytucyjnego, procedur demokratycznego głosowania, systemu hamulców i równowagi, a jedynie kontrakty pomiędzy agencją i jej klientami, która w przypadku konfliktów ma wyłączne prawo sądzenia i posiada monopol na stosowanie siły” (Modrzejewska, 2010, s. 163). Childs (1977) postawił więc pytanie, jakie są gwarancje, że taka firma dobrowolnie rozszerzy ochronę ${ }^{9}$, obejmie nią niezrzeszonych i zatrzyma się na funkcjach państwa minimalnego, a nie stanie się państwem maksymalnym?

\footnotetext{
${ }^{9}$ Może przecież faworyzować dominującą grupę, w zgodzie z twierdzeniem „sprawiedliwość dla silniejszego".
} 
Z kolei wielki przeciwnik, zarówno umowy społecznej, jak i genezy ewolucyjnej, Murray Rothbard wytykał, że przecież wszystkie państwa dotąd powstawały w wyniku przemocy, podboju i wyzysku, uznając rozważania Nozicka za całkowicie wyrwane z kontekstu historycznego. „Niepokalane poczęcie” państwa nie istnieje (Rothbard, 1977). Interesującą ocenę wystosował też Frederic Young, zarzucając teorii Nozicka sprzeczność z fundamentalnymi dogmatami libertarianizmu: zasadą samodecydowania, prawem do samoobrony, swobodną wymianą, wolnością do zawierania umów. Doprowadziło to Younga (1986) do konkluzji, że państwo zapewniło sobie wysoki status w wyniku niedopuszczalnych kroków i jako takie samo w sobie jest niemoralne. Warto także przytoczyć kontrowersyjny pogląd Henri'ego Lepage’a, zawarty w opracowaniu zatytułowanym „Kapitalizm jutra”. Według interpretacji i klasyfikacji Francuza książka Nozicka była w rzeczywistości socjalistyczną refleksją nad państwem (Lepage, 1982). Zarzucił mu czerpanie wprost $\mathrm{z}$ marksistowskiej dialektyki ${ }^{10} \mathrm{i}$ uprawianie historycyzmu ${ }^{11}$.

\section{ANARCHOKAPITALIZM DAVIDA FRIEDMANA}

David Friedman jest synem Miltona Friedmana, który był znacznie mniej skrajny w swoich poglądach niż jego potomek. David został wszechstronnie wykształcony, zdobył fakultety z fizyki, ekonomii oraz prawa, a specjalizuje się w ekonomicznej analizie prawa. Jako filozof uznanie zdobył za sprawą dzieła pt. Mechanizmy wolności - przewodnik po radykalnym kapitalizmie.

W nim Friedman definiuje państwo jako intruza, stojącego w opozycji do instytucji prywatnych. Urzędnicy, za pieniądze podatnika, działają przecież tak,

${ }^{10}$ W rozumieniu Karola Marksa, do dwóch najbardziej podstawowych i naturalnych praw, które rządzą materią, zaliczyć można: prawo przemiany ilości w jakość - polegające na tym, że poszczególne drobne przemiany materii sumują się, aby w pewnym momencie osiągnąć punkt krytyczny, na którego skutek powstaje zupełnie nowa jakość oraz prawo (mechanizm) stałego ścierania się przeciwieństw polegające na tym, że różne jakości materialne są ze sobą w stanie ciągłego antagonizmu. Ścierają się one nieprzerwanie, generując ciąg drobnych przemian, które w końcu prowadzą do nowej jakości, zgodnie z pierwszym prawem.

${ }_{11}$ Termin wprowadzony przez Karla Poppera - pejoratywna nazwa poglądu filozoficznego (neutralną jest historyzm) głoszącego, że w dziejach występuje nieubłagane prawo (przewodnia myśl natury metafizycznej, która rozwija się w określonym kierunku, aby osiągnąć swój konieczny cel). Popper sądził, że w kontraście do prawdziwej nauki, która tworzy falsyfikowalne teorie, taka koncepcja jak marksistowska idea walki klas ma charakter pseudonaukowy, gdyż została skonstruowana tak, że jest w stanie wyjaśnić każdy fakt (każde zdarzenie potwierdza teorię) i nie da się w związku z tym wymyślić dla niej eksperymentu lub choćby obserwacji, która mogłaby ją obalić. 
by zabezpieczać wpływy swojej grupy, a nie troszczyć się o obywateli. „Dlatego naturalna jest antynomia państwowości i prywatności - sił, które rywalizują o prymat w polityce i gospodarce. Autor nie znajduje różnicy między małym a dużym aparatem administracyjnym. Każdy rząd jest zbyt wielki. Jego decentralizacja i prywatyzacja zwiększa kontrolę społeczną i chroni ludność przed nadużyciami ze strony państwa” (Teluk, 2006, s. 168-169). Rząd to „zalegalizowana agencja łamiąca prawa jednostki, różniąca się tym od zwykłego gangu, że większość osób akceptuje jej istnienie jako normalne i słuszne" (Friedman, 1989, s. 112).

Każdy rozumny człowiek powinien nazywać rzeczy po imieniu i odrzucić koncepcję rabującego państwa - Robin Hooda czy Juraja Janosika, zabierającego bogatym, a oddającego biednym. Friedman atakuje też pogląd swojego ojca, że jakoby ograniczony rząd jest w stanie zagwarantować sprawiedliwość. „Logiką rządu ograniczonego jest wzrost. Ta idea pozostaje prawdziwie utopijna” (Friedman, 1989, s. 146).

Friedman sprzeciwia się również stereotypom, takim jak antagonizm praw własności i praw człowieka czy konieczność monopolizacji pewnych dziedzin gospodarki. „Szczególnie monopol państwa uznaje za sprzeczny z interesem leseferystycznego społeczeństwa. Wyjaśnienie szkodliwości istnienia monopoli następuje za pomocą argumentacji ekonomicznej. Monopol wyklucza konkurencję cenową, produkuje więc nieefektywnie, zawyżając ceny i nie licząc się $\mathrm{z}$ kosztami. To niezgodne z zasadami wolnego rynku, a najbardziej poszkodowany jest konsument, pozbawiony możliwości wyboru i zmuszany do nabywania dóbr od jednego dostawcy" (Teluk, 2006, s. 167).

Autor zauważa, że „firmy prywatne zawsze przegrywały na polu monopolizowania rynku z państwem. Rząd za pomocą regulacji prawnych zawczasu stara się wyrugować konkurencję z pewnych sektorów transportu, służby zdrowia, przemysłu ropy naftowej i gazu. Friedman dowodzi, że roszczenie sobie praw do regulowania rynku, jako działanie biurokratów w interesie własnym oraz ich popleczników, zawsze godzi w interes jednostki. Środkiem na naturalną i sprawiedliwą regulację rynkową jest sprzedaż państwa małymi częściami” (Friedman, 1989, s. 53).

Najpierw należy umożliwić wolną konkurencję w zakresie takich usług jak edukacja czy ubezpieczenia. Następnie można posunąć się dalej i sprywatyzować ulice. Friedman wskazuje na to, że „poruszanie się samochodem po drogach miasta wcale nie jest darmowe. Gigantyczne nakłady na infrastrukturę są ponoszone przez podatników przez całe życie. Cóż z tego, skoro ulice są fatalnie utrzymane, 
a korki paraliżują miasta? Koszty bieżące ponoszone są przez obywateli także za pośrednictwem podatków ukrytych w cenie paliwa i samochodów. Dzięki prywatyzacji dróg, zróżnicowaniu opłat w zależności od stanu ich nawierzchni, pory dnia i lokalizacji, koszty transportu mogą radykalnie się obniżyć. Klienci będą wybierali trasę odpowiednią do grubości portfela ${ }^{12}$, poprawi się jakość ulic, zmniejszą się korki i tłok na parkingach. Przedsiębiorczy Amerykanin mógłby oszczędzić na prywatyzacji dróg co najmniej dwa tysiące dolarów rocznie" (Friedman, 1989, s. 73).

Kolejnym krokiem będzie zastąpienie policji i wojska przez prywatne agencje. Ochrona, systemy alarmowe, konwojowanie, dozorowanie to dobra o charakterze ekonomicznym, takie same jak wszelkie inne dobra, które z powodzeniem mogą być zaopatrywane przez firmy prywatne, będące $z$ reguły skuteczniejsze od państwowej policji. „Gdyby tak nie było, to nikt nie korzystałby z ich usług i nie miałyby one racji rynkowego bytu - zbankrutowałyby. Policja nie ma szans stać się bankrutem, bo utrzymuje się z przymusowych podatków i nie podlega prawom rynkowym. Prywatna agencja ochroniarska podlega natomiast konkurencji cenowej. Stara się redukować swoje koszty, aby dostarczyć klientom usługi po dobrej cenie, o najwyższej jakości. Wskutek konkurowania skuteczność agencji ochrony zwiększa się. Dba ona też o zabezpieczenie obywateli przed przestępstwami, gdyż leży to w ich wspólnym interesie" (Teluk, 2006, s. 170).

Warto podkreślić, że prawie dwadzieścia procent społeczeństwa amerykańskiego jest także objęta rozmaitymi, dobrowolnymi programami ochrony społecznej: skierowanymi do zminimalizowania przestępczości wśród młodzieży, monitoringu sąsiedzkiego czy ochrony własności i prywatności. Statystyki wykazują, że samoorganizacja i efektywne zarządzanie bezpieczeństwem lokalnym przez współdziałające, rozproszone stowarzyszenia skuteczniej zapobiegają przestępstwom od metod polityki administracyjnej czy stanowej (Benson, 1990).

W opinii Friedmana fałszywym argumentem przeciwko prywatnej armii jest mniemanie, że sprawiedliwość będzie wymierzana w zależności od militarnej przewagi usługodawcy, gdzie większy podmiot będzie przejmował mniejszy w celu wyeliminowania konkurencji. Teluk zwraca uwagę, że „tego typu rozumowanie jest odpowiednie dla polityki międzynarodowej, nie dla firm wojskowych, które nie są przecież włodarzami terytorium, lecz tylko usługodawcami. Ponadto koszty operacji militarnych są tak gigantyczne, że najzwyczajniej firmom nie

${ }^{12}$ Ludzie, którzy nie użytkowaliby sieci dróg, w ogóle nie ponosiliby opłat. 
opłaci się konkurować siłowymi środkami. Można Friedmanowi dodać jeszcze jeden argument: mianowicie działania wojskowe są zwykle obarczone tak dużym ryzykiem, że działająca w warunkach rynkowych firma nie może sobie pozwolić na opcję niepowodzenia, kompromitującą ją w oczach klientów i będącą silnym czynnikiem na rzecz pokojowego współdziałania. Oponenci tego stanowiska mogliby sugerować, że gdyby nastawione na skuteczność organizacje paramilitarne obawiałyby się porażki, nie dochodziłoby do interwencji z użyciem przymusu, bowiem ryzyka nie sposób wyeliminować. Owszem, jednakże przedsiębiorstwo, a tak należy postrzegać agencję ochrony, ma do dyspozycji szereg innych narzędzi rynkowego konkurowania, np. marketing czy public relations, o wiele tańszych i skuteczniejszych w swoim oddźwięku" (Teluk, 2006, s. $171-172)$.

Ostatecznym ruchem demontującym państwo jest prywatyzacja sądownictwa. Poznanie reguł gospodarczych jest nieodzowne przy egzekwowaniu prawa, dlatego nie ma powodów, aby narzędzie, które służy przecież zapewnieniu zasad uczciwej i efektywnej współpracy, opierało się na innych wartościach, niż te, które podlegają prawom ekonomii (Friedman, 2000). Na jakiej podstawie prywatny sędzia będzie decydował, jakie działania są przestępstwem i jakim karom podlegają? „Odpowiedź jest taka, że system prawa będzie tworzony dla $\mathrm{zysku}^{13}$ na otwartym rynku, tak jak dziś produkowane są książki i biustonosze. Powinna istnieć konkurencja pomiędzy różnymi rodzajami praw, tak jak konkurencja pomiędzy markami samochodów" (Friedman, 1989, s. 116).

Jak można dostrzec, Friedman, zakładając możliwość funkcjonowania prywatnego wymiaru sprawiedliwości, wierzy też w sposobność istnienia wielu systemów prawnych, które zostałyby zweryfikowane w wyniku działania mechanizmów rynkowych. W tym punkcie widać ogromną różnicę dzielącą go z Rothbardem, który „odwołuje się do prawa naturalnego jako determinującego powstanie jednego systemu normatywnego. System zaproponowany przez Friedmana jest konsekwencjonalistyczny i subiektywistyczny" (Barry, 1983, s. 116-117). Rozstrzyganie spraw na zasadzie arbitrażu i finansowej rekompensaty szkód przez przegraną stronę będzie zdeterminowane przez dwustronne porozumienia pomiędzy firmami ochroniarskimi, których klienci są stronami

13 Pomysł autora, jakoby prawo miałoby być konstruowane dla zysku materialnego, zdaje się wynikać z jego fanatycznej wręcz fetyszyzacji rozwiązań rynkowych, niepozwalającej mu spostrzec, że projektowany przez niego koncept byłby w praktyce niewiarygodnie podatny na zachowania niemoralne, wynaturzenia i kartelizację. 
sporu. Według niego tylko taka anarchokapitalistyczna koncepcja jest w stanie zaspokoić rozjemcze potrzeby wolnego społeczeństwa, gdyż prawo byłoby na tyle elastyczne, że dostosowywałoby się nawet do irracjonalnych pragnień i przekonań klientów agencji ochroniarskich (Teluk, 2006). W ten sposób konflikty mogłyby zostać także zażegnane jeszcze przed ich eskalacją.

Friedman nie wyklucza jednocześnie, że w wolnościowym społeczeństwie dojdzie do unifikacji prawa z powodów ekonomicznych i utylitarystycznych. Modrzejewska (2010) sądzi, że w praktyce różnorodność systemów prawnych byłaby ograniczana kosztami prowadzonych pertraktacji. Koszty transakcji, związane z negocjacjami indywidualnego systemu prawnego dla każdej pary osób, czy też dla każdej pary agencji ochronnych, byłyby niezmiernie wysokie i dlatego prawdopodobnie firmy zgodziłyby się na wspólny kodeks prawa, interpretowany przez jedną agencję arbitrażową.

W swoich rozważaniach na temat bezpaństwowego kapitalistycznego ładu Friedman (1989) bardzo często przywołuje historyczne przykłady ustrojów: starożytnej Irlandii oraz - przede wszystkim - średniowiecznej Islandii od X do XIII wieku. System islandzki rozwinął się bez udziału władzy centralnej, porównywalnej do anglosaskiego króla, w rezultacie nawet tam, gdzie określone czyny zostały uznane za zasadniczo publiczne przestępstwa, zajmowano się nimi poprzez danie jednostce prawa do ścigania przestępstwa i ściągania grzywny (w niektórych przypadkach ścigającego wybierano spośród pokrzywdzonych), wpisując się w ten sposób w system prawa prywatnego (Friedman, 2007). Konkludując, za niewątpliwe osiągnięcia islandzkiego wymiaru sprawiedliwości należy uznać skuteczną i uczciwą karalność oraz niski, w porównaniu z innymi ówczesnymi krajami Europy Północnej (Norwegią, Normandią, Anglią), wskaźnik zabójstw. Ponadto ludność, z perspektywy standardów średniowiecznych, była wolna; różnice w statusie społecznym ze względu na płeć czy rangę zaliczyłbym do względnie niewielkich (częściowy wyjątek to status niewolników; szacuje się, że na Islandii nie było ich nigdy więcej niż dwa tysiące, w tym samym czasie, co dawałoby ok. 3\% ludności).

Szukanie prywatnych alternatyw dla trzeciej władzy - systemu sprawiedliwości - być może stanie się bardziej powszechne we współczesnych demokracjach liberalnych. Według Bensona (1990) w USA proces ten już trwa od lat siedemdziesiątych i obecnie programem prywatyzacji bywają objęte: usługi ochroniarskie i wojskowe (przykładowo prywatna organizacja najemnicza Academi, poprzednio nazywana Blackwater), więziennictwo, resocjalizacja oraz usługi sądownicze (mediacje, prywatne sądy). 


\section{ZAKOŃCZENIE}

Czy idee libertariańskie są możliwe do wdrożenia w życie? Moim zdaniem współcześni obrońcy wolności powinni sobie w końcu odpowiedzieć na pewne pytania:

1) czy trzeba postrzegać tylko własność i wolność jako podstawowe i nadrzędne wartości społeczne? Czy ich gwarantowanie musi być faktycznie jedynym celem państwa?

2) czy ludzie nie życzą sobie interwencji państwa?

3) czy słuszną drogą do realizacji swoich pomysłów jest zamykanie się wewnątrz własnej grupy i nazywanie wszystkich dookoła antywolnościowcami?

Wszystkie odpowiedzi na te pytania wydają się być negatywne:

Ad 1. Głównymi, równouprawnionymi zasadami mogą być dla kogoś: prawo do życia, prawo do prywatności, równość szans czy sprawiedliwość społeczna. Państwo może też mieć postawione zupełnie odmienne cele ideologiczne, takie jak: zagwarantowanie każdemu obywatelowi dobrobytu, zapewnienie wysokiego przyrostu naturalnego własnemu narodowi, rozwój własnej cywilizacji i ochrona przed zderzeniem $\mathrm{z}$ innymi czy pomoc każdej osobie w ostatecznym zbawieniu i zjednoczeniu się z Bogiem.

Ad 2. Regulacje prawne znajdują czasem głębokie uzasadnienie (racjonalne bądź moralne) i mogą być dobrowolnie przyjmowane przez jednostki. Choć ograniczają wolność i swobodę działania w pewnym aspekcie, to mogą one zapewniać bezpieczeństwo, a być może także wolność jako taką. Przykładem jest dobrowolna zgoda ludzi na ograniczenia przeciwpowodziowe, przeciwpożarowe, sanitarno-epidemiologiczne (Orczyk, 2008) czy ruchu drogowego ${ }^{14}$, które blokują ich swobodę działania, ale zwiększają poziom bezpieczeństwa. A przecież cała gospodarka jest mechanizmem po tysiąckroć bardziej skomplikowanym od ruchu drogowego, więc nie można odmówić państwu funkcji rejestracyjnej (z czym, spośród grona libertarian zgadzał się tylko Friedrich von Hayek, odchodząc tym samym od ścisłego libertarianizmu) oraz pełnienia roli ustalającego minimalne ramy i reguły jej funkcjonowania. Wykonywanie zawodu lekarza czy prawnika było przecież regulowane od samego początku istnienia tych profesji. Zdaje się również niemożliwe całkowite odejście państwa od takich sfer, jak

${ }^{14}$ Inną sprawą jest oczywiście to, iż możemy dyskutować, czy tych przepisów rzeczywiście nie istnieje za dużo. 
ratownictwo medyczne i opieka zdrowotna, ubezpieczenia rentowe i emerytalne oraz edukacja nieletnich ${ }^{15}$, gdyż masy po prostu się na to nie zgodzą, a gdyby ich do tego zmusić, prędzej czy później, z powodu kolosalnych nierówności, nękani chorobami, głodem i skłoni do agresji, po prostu by się zbuntowali i obalili taki reżim.

Ad 3. Ta strategia nie przynosi pozytywnych rezultatów, dlatego warto rozważyć założenie wielkiej wolnorynkowej rodziny, doprowadzając do zbliżenia, w wymiarze działalności praktycznej (politycznej i edukacyjnej), różnych środowisk potencjalnych sojuszników, takich jak konserwatywni liberałowie, centowi liberałowie czy klasyczni liberałowie. Razem z nimi jest prawdopodobne stworzenie przeciwwagi dla lewicowych anarchistów i propaństwowych socjaldemokratów. Oczywiście w ten sposób libertarianie utraciliby nieco z atutu logiczności swojej koncepcji, ale zyskaliby realną szansę na realizację chociaż części swych pomysłów.

Pozostaje kwestia ich osiągnięcia. W tym wypadku, wolnościowcy już od dawna dzielą się na dwa fronty:

1) pierwszy blok uważa, że warto walczyć, by nałożyć ograniczenia na władzę państwa, zapobiegać rozrastaniu się skostniałego rządu i interwencjonizmu, wewnątrz obecnego schematu. Ma tu na myśli najpierw kontrolę wydatków publicznych, redukcję budżetu, budżet zrównoważony, następnie ustanowienie precyzyjnej separacji kompetencji władz: ustawodawczej, wykonawczej (rząd nie ma prawa tworzyć ustaw) i sądowniczej, z faktyczną zasadą izonomii, zapewniającą obywatelom prawdziwą równość wobec prawa ${ }^{16}$, a także prawo do równego udziału we władzy, a ostatecznie postawienie konkretnego limitu działań państwa w postaci nowej konstytucji liberalnego ustroju, który zastąpi demokrację absolutną.

2) druga formacja bez mówienia, że jest to negatywne, dochodzi do wniosku, że wolność nie może być kompatybilna z systemem, jaki znamy. Jej filozofią jest rozmontowanie współczesnych państw na kawałki, im mniejsze, tym lepsze. Przykładowo, takie jak dziewiętnastowieczne Niemcy przed

15 Przykładowe rozwiązania liberalne: przymus wyboru dowolnego, prywatnego towarzystwa ubezpieczeniowego, obligatoryjne odkładanie części środków pieniężnych na zamrożonym, prywatnym koncie bankowym, zaadaptowanie struktury emerytur kanadyjskich, wprowadzenie systemu bonów oświatowych.

${ }^{16}$ Oznacza to rezygnację z uprzywilejowywania, np. pewnych grup zawodowych. 
zjednoczeniem, oparte na wolnych stanach ${ }^{17}$ oraz niepodległych miastach, $\mathrm{z}$ istnieniem swobody językowej, z wolnością handlową i wolnością przekraczania granic. Podążając tym tropem, cała różnorodna Europa, z tysiącem małych państw, zjednoczonych przez autostrady fizyczne i informatyczne oraz z jedną niepubliczną walutą (złotem), stałaby się rogiem obfitości i ogromną siłą cywilizacyjną ${ }^{18}$.

Konkludując, wydaje mi się, że za libertarianami stoją siły rynku, które uruchamiają wręcz niewyobrażalne pokłady przedsiębiorczości i mogą one okazać się niezwyciężone, zmuszając nieefektywne rządy do odwrotu z pogłębiania globalnego deficytu, a wejścia na drogę samoograniczania się (np. poprzez antyfiskalizm) i powierzania coraz szerszych kompetencji firmom prywatnym (np. wspaniała propozycja sądów arbitrażowych i odszkodowań w zamian za nieskuteczne i nieetyczne, bo finansowane z funduszy wszystkich podatników, kary pozbawiania wolności). Przewidywanie przyszłości pozostawiam jednak futurologom.

\section{BIBLIOGRAFIA:}

Barry, N. (1983). The New Liberalism. British Journal of Political Science.

Barry, N. (1984). Unanimity Agreement and Liberalism: A Critique of James Buchanan's Social Philosophy. Political Theory.

Benson, B. (1990). The Enterprise of Law - Justice without the State. San Francisco: Pacific Research Institute for Public Policy.

Buchanan, J. (1977). Freedom in Constitutional Contract: Perspectives of a Constitutional Economist. Texas: University Press.

Buchanan, J. (1975). The Limits of Liberty: Between Anarchy and Leviathan. Chicago: University Press.

Buchanan, J., Tullock, G. (1979). The Calculus of Consent. http://www.econlib.org/ library/Buchanan/buchCv3Cover.html.

Childs, R. (1977). The Invisible Hand Strikes Back. The Journal of Libertarian Studies.

Friedman, D. (1989). The Machinery of Freedom - Guide to a Radical Capitalism. La Salle: Open Court.

Friedman, D. (2000). Law's Order - An Economic Account. Princeton: University Press. Friedman, D. (2007). Prywatne tworzenie i egzekwowanie prawa: przypadek historyczny. http://liberalis.pl/2007/06/16/david-friedman-prywatne-tworzenie-iegzekwowanie-prawa/.

${ }^{17}$ Johann W. von Goethe był jednym z ministrów takiego stanu, miał tylko sześćdziesięciu żołnierzy. Taką ich liczbą nie można wyrządzić wielu szkód. Naród niemiecki zaczął krzywdzić innych dopiero wtedy, kiedy się połączył.

18 Ale nie militarną, co mogłoby grozić najazdem przez scentralizowane imperium. 
Legutko, R. (1997). Etyka absolutna i społeczeństwo otwarte. Kraków: Arcana.

Lepage, H. (1982). Tommorow Capitalism. La Salle: Open Cort Publishing Company.

Lemieux, P. (1983). Du liberalisme a l'anarcho-capitalisme. Paris: PUF.

Locke, J. (1992). Dwa traktaty o rzadzie. Warszawa: Wydawnictwo PWN.

Miklaszewska, J. (2001). Filozofia i ekonomia - w kręgu teorii publicznego wyboru. Kraków: Wydawnictwo Uniwersytetu Jagiellońskiego.

Modrzejewska, M. (2010). Libertariańskie koncepcje jednostki i państwa we współczesnej amerykańskiej myśli politycznej. Kraków: Wydawnictwo Uniwersytetu Jagiellońskiego.

Naverson, J. (1988). The Libertarian Idea. Philadelphia: Temple University Press.

Nozick, R. (2010). Anarchia, państwo, utopia. Warszawa: Wydawnictwo Aletheia.

Orczyk, J. (2008). Polityka społeczna: uwarunkowania i cele. Poznań: Wydawnictwo Akademii Ekonomicznej w Poznaniu.

Paul, R. (2008). Wolność pod ostrzałem. Warszawa: Wydawnictwo Prohibita.

Porębski, C. (1999). Umowa społeczna - renesans idei. Kraków: Wydawnictwo Znak.

Rawls, J. (1994). Teoria sprawiedliwości. Warszawa: Wydawnictwo PWN.

Rothbard, M. (1977). Robert Nozick and the Immaculate Conception of the State. The Journal of Libertarian Studies.

Teluk, T. (2006). Libertarianizm - teoria państwa. Warszawa: 2S Media.

Weber, M. (1964). The Theory of Social and Economic Organization. New York: Free Press.

Wicksell, K. (1896). Finanztheoretische Untersuchungen. Jena: G. Fisher.

Wilkin, J. (2005). Teoria wyboru publicznego - wstęp do ekonomicznej analizy polityki i funkcjonowania sfery publicznej. Warszawa: Wydawnictwo Naukowe Scholar.

Young, F. (1986). Nozick and Individualist Anarchist. The Journal of Libertarian Studies. 